\title{
Pengaruh Konsentrasi Agar-Agar Terhadap Karakteristik Kimia dan Sensori Permen Jelly Buah Mangga Kweni (Mangifera odorata Griff)
}

\author{
Effects of Agar Concentrations on the chemical and sensory characteristics of Kweni \\ Mango (Mangifera odorata Griff) Jelly Candy
}

\author{
Nenengsih Verawati ${ }^{1}$, Nur Aida ${ }^{2}$, Assrorudin $^{3}$, Andre Wijayanto ${ }^{4}$ \\ ${ }^{1}$ Program Studi Teknologi Pengolahan Hasil Perkebunan, Politeknik Negeri Ketapang, Jl. Rangga Sentap, \\ Ketapang 78813, Kalimantan Barat, Indonesia \\ ${ }^{2}$ Program Studi Teknik Sipil, Politeknik Negeri Ketapang, Jl. Rangga Sentap, Ketapang 78813, Kalimantan \\ Barat, Indonesia \\ ${ }^{3}$ Program Studi Agroindustri, Politeknik Negeri Ketapang, Jl. Rangga Sentap, Ketapang 78813, Kalimantan \\ Barat, Indonesia \\ ${ }^{4}$ Alumni Program Studi Teknologi Pengolahan Hasil Perkebunan, Politeknik Negeri Ketapang \\ Jl. Rangga Sentap, Ketapang 78813, Kalimantan Barat, Indonesia \\ *Penulis Korespondensi: Nenengsih Verawati, email: nenengverawati6@gmail.com
}

Tanggal submisi: 23 Maret 2020; Tanggal penerimaan: 01 Juli 2020

\begin{abstract}
Kweni mango is one type of mangoes with natural vitamin A, vitamin B6, vitamin $C$, and high fiber. This study aimed to determine agar's effect on the chemical and sensory properties of kweni mango jelly candies. A completely randomized experimental design was applied in this research with three treatment levels, i.e., 2, 3, and 4\% of agar. The results showed that agar addition did not significantly affect the moisture and vitamin $C$ content of jelly candies. The moisture and vitamin content of the candies were 1.40$1.50 \%$ and $48.37-72.28 \mathrm{mg} / 100 \mathrm{~g}$, respectively. Panelists, in general, liked (7.28) the taste and texture of the candies with $3 \%$ agar.
\end{abstract}

Keywords: agar, kweni fruit, jelly candies

\begin{abstract}
ABSTRAK
Mangga kweni adalah salah satu buah manga yang memiliki sumber vitamin A, vitamin B6, vitamin C dan serat yang tinggi. Tujuan Penelitian adalah untuk mengetahui pengaruh konsentrasi agar-agar terhadap karakteristik kimia dan sensori permen jelly buah mangga kweni. Penelitian ini menggunakan metode eksperimen rancangan acak lengkap satu faktor yaitu konsentrasi agar-agar 2\%, 3\% dan 4\%. Hasil penelitian menunjukkan bahwa penambahan agar-agar tidak memberikan pengaruh terhadap kadar air dan vitamin $\mathrm{C}$ pada permen jelly. Mutu kimia kadar air diperoleh 1,40-1,50\% dan vitamin C 48,37-72,28 mg/100 g. Ratarata panelis menyatakan suka terhadap rasa dan tektur dengan rata rata skor 7,28 pada agar-agar $3 \%$.
\end{abstract}

Kata kunci: agar, mangga kweni, permen jelly

\section{PENDAHULUAN}

Permen jelly merupakan permen yang terbuat dari campuran sari buah-buahan, bahan pembentuk gel atau dengan penambahan essens untuk menghasilkan berbagai macam rasa, dengan bentuk fisik jernih transparan serta mempunyai tekstur kenyal (Hasyim et al., 2015). Permen jelly yang dibuat dari buah ataupun sayuran memiliki kelebihan akan nilai nutrisi dibandingkan dengan 
ada di pasaran yang hanya berasal dari penambahan essen dari bahan kimia. Kulit buah naga dan ekstrak angkak telah dibuat menjadi permen jelly dengan perlakuan terbaik, kulit buah naga $30 \%$ dan ekstrak angkak 2\% (Afifah et al., 2017).

Permen jelly memiliki daya simpan yang cukup lama, disebabkan karena pengaruh dari penggunaan gula menyebabkan menurunnya kadar air pada produk (Hidayat dan Ikariztina, 2004). Umumnya buah kweni dibuat dari jenis buah, atau penambahan essens buah. Salah satu buah yang belum dimanfaatkan secara maksimal adalah buah kweni di Kabupaten Ketapang Kalimantan Barat.

Mangga kweni (Mangifera odorata Griff) adalah buah dengan aroma yang khas pada buahnya, sehingga buah ini berbeda dengan buah mangga lainnya (Putri et al., 2017). Mangga merupakan buah musiman yang memiliki sifat mudah rusak karena kandungan airnya yang tinggi (Mandey dan Mamuaja, 2016). Mangga kweni memilik beberapa komposisi kimia yaitu vitamin A, vitamin B6, vitamin $\mathrm{C}$ dan serat yang tinggi. Penambahan mangga kweni pada pembuatan permen jelly akan menambah nilai gizi dan menghasilkan aroma yang khas pada permen jelly. Faktor penentu permen jelly yang baik yaitu nilai gizi, aroma dan tekstur yang kenyal. Salah satu penentu tekstur yang kenyal dalam pembuatan permen adalah penambahan agar-agar. Agar-agar terbuat dari rumput laut yang mempunyai sifat hidrokoloid yang tidak larut pada air dingin namun larut pada air panas (Wulandari, 2015).

Berdasarkan latar belakang di atas sehingga peneliti mengambil judul pengaruh konsentrasi agar-agar terhadap karakteristik kimia dan sensori permen jelly buah mangga kweni. Penelitian ini

Tabel 1. Rekapitulasi hasil uji organoleptik bertujuan untuk mendapatkan pengaruh konsentrasi agar-agar terhadap karakteristik kimia dan sensori permen jelly buah mangga kweni.

\section{METODE PENELITIAN}

\section{Bahan}

Bahan yang digunakan dalam pembuatan permen jelly mangga kweni adalah buah mangga kweni yang telah matang dan beraroma harum, gula pasir, agar-agar, air bersih dan asam sitrat.

\section{Pelaksanaan Penelitian}

\section{Pembuatan Permen Jelly Buah Mangga Kweni (Isnanda, 2016)}

Tahap awal penelitian dimulai dengan pemilihan buah mangga yang masak rata, dicuci, dikupas, diambil daging buahnya sebanyak $500 \mathrm{~g}$, diblender, disaring, dicampur dengan gula sebanyak $250 \mathrm{~g}$, agar-agar $(6,9$, dan $12 \mathrm{~g})$ dan asam sitrat $0,3 \mathrm{~g}$, kemudian dimasak sampai kental selama 30 menit suhu $80^{\circ} \mathrm{C}$, setalah masak dimasukkan dalam cetakan, didinginkan. Setelah dingin, dikeringkan dengan pengering kabinet pada suhu $50^{\circ} \mathrm{C}$ selama 8 jam. Permen jelly yang sudah kering dikemas.

\section{Pengamatan}

Pengamatan yang dilakukan pada permen jelly yaitu uji organoleptik berdasarkan mutu hedonik yang meliputi; rasa, tekstur, dan aroma. Selanjutnya diuji secara kimia meliputi uji kadar air (metode pengeringan oven) dan vitamin C metode yodium (Sudarmadji, 1989).

\begin{tabular}{lcccccccccc}
\hline & \multicolumn{9}{c}{ Atribut Penilaian } \\
\cline { 2 - 11 } \multicolumn{1}{c}{ Skala Penilaian } & \multicolumn{3}{c}{ Rasa } & \multicolumn{3}{c}{ Aroma } & \multicolumn{3}{c}{ Tekstur } \\
\cline { 2 - 12 } & 333 & 444 & 555 & 333 & 444 & 555 & 333 & 444 & 555 \\
\hline 1. Amat sangat tidak suka & 0 & 0 & 0 & 0 & 0 & 0 & 0 & 0 & 0 \\
2. Sangat tidak suka & 0 & 0 & 0 & 0 & 0 & 0 & 0 & 0 & 0 \\
3. Tidak suka & 1 & 0 & 1 & 0 & 0 & 1 & 1 & 0 & 1 \\
4. Agak tidak suka & 0 & 0 & 2 & 0 & 0 & 1 & 1 & 1 & 2 \\
5. Netral & 1 & 2 & 0 & 0 & 3 & 1 & 1 & 2 & 1 \\
6. Agak suka & 5 & 2 & 2 & 4 & 2 & 1 & 1 & 2 & 1 \\
7. Suka & 7 & 11 & 10 & 11 & 13 & 11 & 12 & 10 & 7 \\
8. Sangat suka & 7 & 7 & 7 & 7 & 4 & 6 & 5 & 6 & 9 \\
9. Amat sangat suka & 4 & 3 & 3 & 3 & 3 & 4 & 4 & 4 & 4 \\
\hline
\end{tabular}


Tabel 2. Kadar air permen jelly

\begin{tabular}{cccc}
\hline $\begin{array}{c}\text { Konsentrasi Sari } \\
\text { Mangga Kweni }\end{array}$ & Konsentrasi Agar-agar & $\begin{array}{c}\text { Rata-rata } \pm \text { Standar } \\
\text { Deviasi }\end{array}$ & Standart Permen Jelly \\
\hline $300 \mathrm{~mL}$ & $2 \%$ & $1,49 \%$ & \\
$300 \mathrm{~mL}$ & $3 \%$ & $1,41 \%$ & Mak $20 \%$ \\
$300 \mathrm{~mL}$ & $4 \%$ & $1,38 \%$ & \\
\hline
\end{tabular}

\section{Analisis Data}

Data hasil penelitian dianalisis secara statistik menggunakan rancangan acak lengkap terdiri atas tiga ulangan, bila terdapat perbedaan yang nyata atau sangat nyata maka pengujian dilanjutkan dengan uji beda nyata terkecil (BNT, $\alpha$ $=0,05$ ).

\section{HASIL DAN PEMBAHASAN}

\section{Kadar Air}

Pengukuran kadar air bertujuan untuk mengetahui kadar air produk yang dihasilkan dengan berbagai perlakuan sehingga dapat diperkirakan daya tahan produk. Kadar air bahan pangan sangat mempengaruhi mutu dari bahan pangan tersebut. Kadar air yang tinggi akan mengakibatkan perubahan kimia, perubahan warna dan lainnya pada produk pangan sehingga daya awetnya menurun (Afifah et al., 2017). Hasil pengukuran kadar air dari berbagai perlakuan pada permen jelly dapat dilihat pada Tabel 2.

Hasil analisis keragaman konsentrasi agaragar berpengaruh sangat nyata $(\mathrm{p}<0,01)$ terhadap kadar air. Hasil penelitian menunjukkan bahwa ketiga perlakuan perbedaan konsentrasi agar-agar menghasilkan kadar air yang berbeda. Kadar air tertinggi terdapat pada perlakuan konsentrasi sari mangga kweni $300 \mathrm{~mL}$ dan konsentrasi agar-agar $2 \%$ dengan rata-rata kadar air 1,52\% dan kadar air terendah terdapat pada konsentrasi sari mangga kweni $300 \mathrm{~mL}$ dan konsentrasi agar-agar 4\% dengan rata-rata kadar air 1,39 \% dari tabel tersebut menunjukkan semakin tingginya konsentrasi agar-agar maka kadar air semakin menurun, dan semakin rendah konsentrasi agar-agar maka kadar air semakin tinggi. Hal ini disebabkan semakin banyak konsentrasi agar-agar yang ditambahkan maka jumlah padatan akan semakin banyak dan kadar air produk akan menurun (Marsigit et al., 2018). Karagenan dan agar-agar merupakan bahan pengemuilsi, penstabil dan pengental yang dapat menstabilkan sistem disperse yang homogen.
Selain itu dapat meningkatkan viskositas bahan dan juga meningkatkan total padatan terlarut yang nantinya akan mengurangi kadar air bahan itu sendiri (Juwita et al., 2014). Penelitian tersebut sesuai dengan hasil perlakuan ini dimana konsentrasi sari manga kweni $300 \mathrm{~mL}$ dengan konsentrasi yang agar-agar yang sedikit yaitu $2 \%$ menghasilkan kadar air yang lebih tinggi dari konsentrasi agar-agar $4 \%$.

Menurut Atmaka et al. (2013), pembentukan gel adalah suatu pengikatan silang rantai-rantai polimer sehingga membentuk suatu jala tiga dimensi bersambung, selanjutnya jala ini dapat menangkap air di dalamnya sehingga dapat membentuk struktur yang kuat dan kaku. Jika dibandingkan dengan Standar Nasional Indonesia permen jelly, kadar air permen jelly hasil penelitian telah memenuhi standar kadar air permen jelly sesuai dengan SNI (2008) yaitu sebesar 20\%.

\section{Vitamin C}

Vitamin C adalah salah satu vitamin (nutrisi) yang sangat diperlukan oleh tubuh serta mempunyai fungsi untuk meningkatkan daya tubuh (sistem imunitas tubuh). Vitamin atau asam askorbat dengan rumus molekul $\mathrm{C}_{6} \mathrm{H}_{8} \mathrm{O}_{6}$. Dalam bentuk Kristal tidak bewarna, titik cair $190-192{ }^{\circ} \mathrm{C}$ bersifat larut air sedikit larut dalam aseton atau alkohol yang mempunyai berat molekul rendah (Supandi, 2015). Hasil pengukuran vitamin C dari berbagai perlakuan pada permen jelly yang dihasilkan dapat dilihat pada Tabel 3.

Hasil analisis keragaman perlakuan konsentrasi agar-agar berpengaruh sangat nyata $(p<0,01)$ terhadap kadar vitamin $\mathrm{C}$ permen jelly. Hasil penelitian menunjukkan bahwa ketiga perlakuan perbedaan konsentrasi agar-agar mengha-silkan kadar Vitamin C yang berbeda. Hasil tertinggi terdapat pada permen jelly mangga kweni dengan konsentrasi $4 \%$. Semakin banyak penambahan agar-agar maka kadar vitamin $\mathrm{C}$ permen jelly semakin meningkat. 
Tabel 3. Vitamin C permen jelly

\begin{tabular}{ccc}
\hline Konsentrasi Sari Mangga Kweni & Konsentrasi Agar-agar (\%) & Rata-rata (\%) \\
\hline $300 \mathrm{~mL}$ & 2 & 47,72 \\
$300 \mathrm{~mL}$ & 3 & 49,93 \\
$300 \mathrm{~mL}$ & 4 & 51,58 \\
\hline
\end{tabular}

Agar-agar merupakan bahan pembentuk gel terbuat dari rumput laut yang memiliki kandungan vitamin C $100-800 \mathrm{mg} / \mathrm{kg}$ per berat kering (sahri, 2009). Konsentrasi agar-agar yang tinggi mampu membentuk disperse koloid (struktur double helix) yang lebih banyak dan kuat sehingga akan menghambat oksidasi vitamin $\mathrm{C}$ dan agar lebih kuat melindungi vitamin $\mathrm{C}$ dengan matrik yang kuat (Niati et al., 2018). Mangga kweni mengandung $61,3980 \mathrm{mg} / 100 \mathrm{~g}$ kadar vitamin $\mathrm{C}$ (Sebayang et al., 2017). Vitamin C merupakan vitamin yang mudah rusak dibandingkan dengan jenis vitamin yang lain, disamping mudah larut dalam air, vitamin $\mathrm{C}$ juga mudah teroksidasi yang dipercepat oleh panas, proses pembuatan permen jelly mengalami proses pemanasan sehingga kadar vitamin C berkurang dalam produk (Miranti et al., 2017). Hasil penelitian menunjukkan bahwa konsentrasi agar-agar $4 \%$ merupakan konsentrasi terbaik dalam pembuatan permen jelly.

\section{Rasa}

Rasa berbeda dengan bau dan lebih banyak melibatkan panca indra yang sulit dimengerti secara tuntas karena selera manusia sangat beragam. Umumnya makanan tidak hanya terdiri dari satu kelompok rasa saja, tetapi merupakan gabungan dari berbagai rasa yang terpadu sehingga menimbulkan rasa makanan yang enak. Rasa merupakan salah satu faktor yang mempengaruhi penerimaan seseorang terhadap suatu makanan. Rasa secara umum dapat dibedakan menjadi asin, manis, pahit, asam, dan umami (Chaudhari dan Roper, 2010). Hasil pengukuran rasa dari berbagai perlakuan pada permen jelly yang dihasilkan dapat dilihat pada Gambar 1.

Gambar 1 menunjukan bahwa nilai rata-rata tertinggi terdapat pada rasa permen jelly dengan perlakuan 3\% yaitu dimana sari buah mangga kweni $300 \mathrm{Ml}$ dan agar-agar $9 \mathrm{~g}$ sedangkan nilai rata-rata terendah terdapat pada perlakuan $4 \%$ dimana sari buah mangga kweni $300 \mathrm{~mL} 12 \mathrm{~g}$ agar-agar.

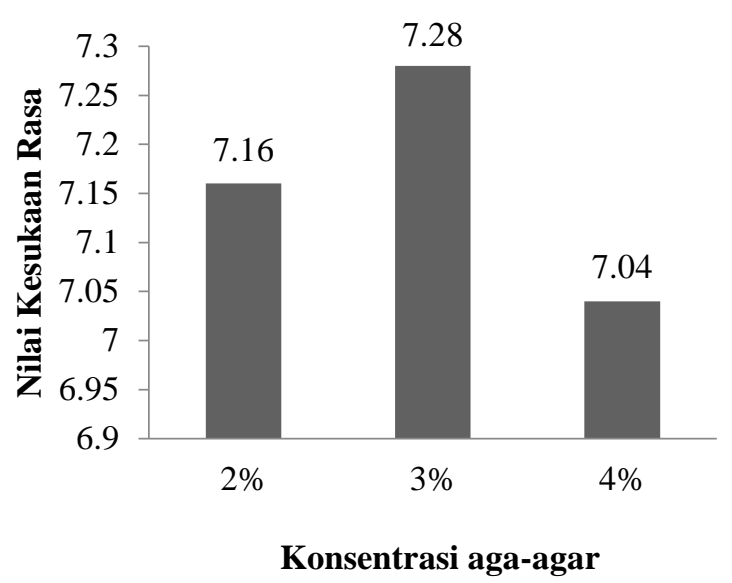

Gambar 1. Grafik kesukaan terhadap rasa permen jelly

Hasil analisis keragaman menyatakan bahwa tidak terdapat perbedaan yang nyata antara ketiga perlakuan yang berarti bahwa respon panelis terhadap rasa yang dihasilkan adalah sama, hal ini diduga semakin tinggi konsentrasi agar-agar yang ditambahkan maka rasa dari buah kweni akan tertutupi oleh agar-agar sehingga penelis hanya merasakan rasa manis dari gula. Penambahan gelatin dapat menutup rasa asli dari buah nanas yang ditambahkan pada permen jelly sehingga menyebabkan rasa kurang manis pada permen jelly nanas (Isnanda, 2016). Menurut Engka (2016). Bahwa sukrosa berfungsi memberi rasa manis, Sifat dari sukrosa yang dapat mengikat air sehingga dapat mengurangi kadar air pada bahan.

\section{Aroma}

Aroma adalah salah satu bagian terpenting dari suatu produk, karena aroma bisa menggambarkan kelezatan yang dimiliki produk tersebut, aroma makanan beras dari molekulmolekul yang menguap dari makanan tersebut yang tertangkap hidung sebagai indra pembau (Winarno, 2004). Hasil pengukuran uji organoleptik aroma dari berbagai perlakuan pada permen jelly yang dihasilkan dapat dilihat pada Tabel 3. 


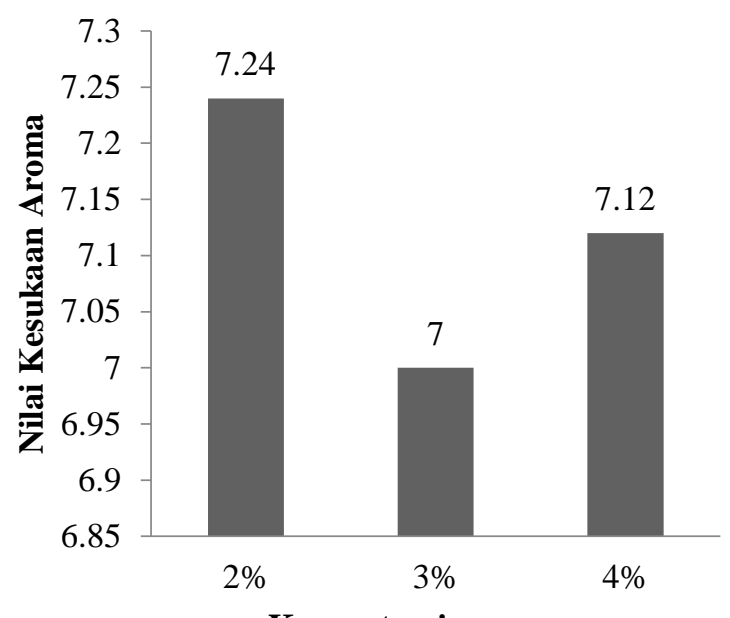

Konsentrasi agar-agar

Gambar 2. Grafik kesukaan terhadap aroma permen jelly

Gambar 2 menunjukkan bahwa nilai ratarata tertinggi pada permen jelly terdapat pada pelakuan $2 \%$ yaitu sari mangga 300 dan 6 g agaragar, dan nilai rata-rata terendah pada perlakuan 3\% yaitu 300 sari mangga dan 9 g agar-agar.

Hasil analisis keragaman menunjukkan bahwa tidak ada perbedaan nyata antara ketiga perlakuan yang berarti bahwa respon panelis terhadap aroma yang dihasilkan pada permen jelly adalah sama. Hal ini dikarenakan konsentrasi buah mangga yang sama yaitu $300 \mathrm{~mL}$. Buah kweni saat masak mempunyai aroma yang khas (Sachlan et al., 2019), yang membuat panelis menyukai aroma dari permen jelly mangga kweni. Menurut Winarno (2004), komponen yang memberikan aroma adalah asam-asam organik berupa ester dan volatil, secara kimiawi sulit dijelaskan mengapa senyawasenyawa menyebabkan aroma yang berbeda. Senyawa-senyawa yang mempunyai struktur kimia dan gugus fungsional yang hampir sama kadangkadang mempunyai aroma yang berbeda. Pengujian bahan pangan terhadap aroma dalam industri pangan sangat penting karena dapat memberikan penilaian industri hasil olahannya (Basuki et al., 2014).

\section{Tekstur}

Salah satu parameter mutu yang sangat berperan penting dalam penampilan karakteristik permen adalah tekstur. Hal ini mempunyai hubungan dengan rasa pada waktu mengunyah bahan tersebut, sensasi yang didapatkan saat mangkonsumsi permen pada dasarnya adalah perpaduan tekstur. Tekstur pada makanan dapat diukur berdasarkan indra peraba yaitu ujing jari tangan, parameter penting dari penilaian tekstur adalah keras, kenyal, berpasir, berminyak dan berair (Setyaningsing et al., 2010). Hasil pengukuran uji organoleptik tekstur dari berbagai perlakuan pada permen jelly yang dihasilkan dapat dilihat pada Gambar 3.

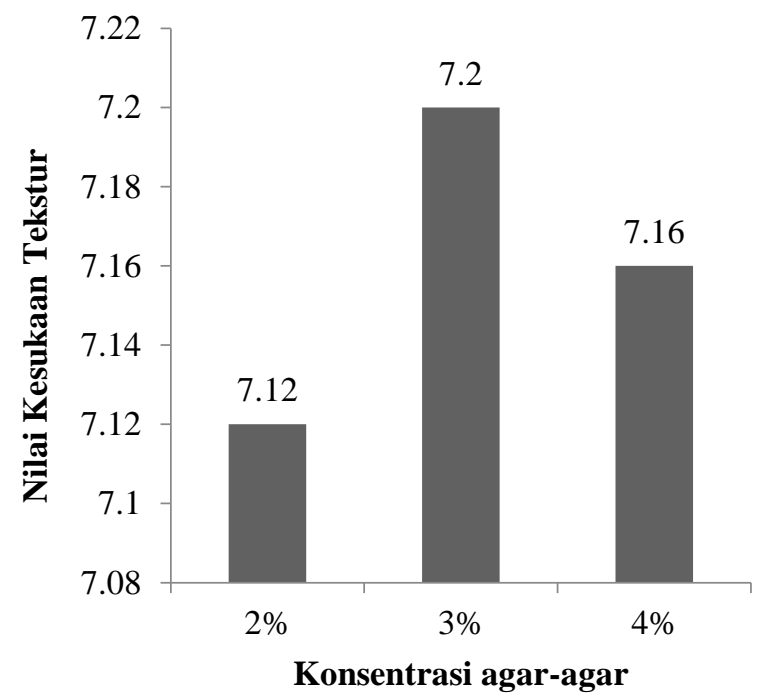

Gambar 3. Grafik uji kesukaan tekstur permen jelly

Gambar 3 menunjukkan bahwa nilai ratarata tertinggi terdapat pada permen jelly perlakuan $3 \%$ yaitu $300 \mathrm{~mL}$ sari mangga dan $9 \mathrm{~g}$ agar-agar dan nilai rata-rata terendah pada permen jelly terdapat pada perlakuan $2 \%$ agar-agar $6 \mathrm{~g}$.

Hasil perhitungan analisis keragaman menyatakan bahwa tidak terdapat perbedaan yang nyata dari ketiga perlakuan yang berarti bahwa respon panelis pada permen jelly sama, hal ini disebabkan oleh penambahan dari agar-agar tersebut. Semakin tinggi penambahan konsentrasi agar-agar maka tekstur permen akan lebih kenyal sampai kaku hal ini disebabkan semakin banyak konsentrasi agar agar didalam bahan maka jumlah padatan akan semakin banyak dan kadar air bahan akan menurun dan jika konsentrasi terlalu rendah maka gel akan lunak atau bahkan tidak membentuk gel (Rahmi et al., 2012). Perubahan tekstur dapat disebabkan oleh hilangnya kandungan air atau lemak, pecahnya, emulsi, hidrolisis, karbohidrat dan kougulasi atau hidolisis protein (Fellows, 1990).

\section{KESIMPULAN}

Beberapa hal yang dapat disimpulkan dari penelitian tersebut yaitu sebagai berikut: 1) proses 
pembuatan permen pada penelitian ini dari persiapan bahan dan alat, mangga dicuci, dipotong, dihaluskan, penyaringan, penambahan bahan, pemasakan, dioven, dan dikemas; dan 2) konsentrasi agar-agar pada permen jelly mangga kweni berdasarkan uji organoleptik yang paling disukai oleh panelis dari segi rasa dan tekstur permen jelly adalah perlakuan $3 \%$ dan untuk aroma yang paling disukai oleh panelis dengan perlakuan $2 \%$, hasil kadar air dari semua perlakuan yaitu $2 \%=1,50,3 \%=1,45$ dan $4 \%=1,40 \%$ memiliki kadar air memenuhi standart mutu permen jelly (maks 20\%), dan memiliki kadar vitamin $\mathrm{C} 2 \%=48,37 \mathrm{mg} / 100 \mathrm{~g}, 3 \%=52,7$ $\mathrm{mg} / 100 \mathrm{~g}$ dan $4 \%=57,10 \mathrm{mg} / 100 \mathrm{~g}$.

\section{DAFTAR PUSTAKA}

Afifah, K., E. Sumaryati, dan M. Su'i. 2017. Studi pembuatan permen jelly dengan variasi konsentrasi sari kulit buah naga (Hylocereus costaricencis) dan ekstrak angkak. Jurnal Ilmu-Ilmu Pertanian AGRIKA 11: 206-220.

Atmaka, W., E. Nurhartadi, dan M.M. Karim. 2013. Pengaruh Penggunaan Campuran Karakagen dan Konjak Terhadap Karakteristik Permen Jelly Temulawak (Curcuma xanthorrhiza Roxb). Jurusan Teknologi Hasil Pertanian. Fakultas Pertanian. Universitas Sebelas Maret. Surakarta.

Basuki, E.K.S., T.S. Mulyani, dan L. Hudayati. 2014. Pembuatan permen jelly nanas dengan penambahan karagenan dan gelatin. Jurnal Rekapangan 8: 39-49.

Chaudhari, N. and S.D. Roper. 2010. The cell biology of taste. Journal of Cell Biology 190: 285-296. DOI: 10.1083/jcb.201003144

Engka, L.D. 2016. Pengaruh Konsentrasi Sukrosa dan Sirup Glukosa Terhadap Sifat Kimia dan Sensoris Permen Keras Belimbing Wuluh (Averrhoa bilimbing L.). Jurusan Teknologi Pertanian. Fakultas Pertanian. Universitas Sam Ratulangi. Manado.

Fellows, P.J. 1990. Food Processing Technology; Principles and Horwood Limited, England.

Hasyim, H., A. Rahim, dan Rostiati. 2015. Karakteristik fisik dan kimia dan organoleptik permen jelly dari sari buah srikaya pada variasi konsentrasi agar-agar. e-Jurnal Agrotekbis 3: 463-474.
Hidayat, N. dan K. Ikariztina. 2004. Membuat Permen Jelly. Surabaya: Penerbit Trubus Agrisana.

Isnanda, D., M. Novita, dan S. Rohaya. 2016. Pengaruh konsentrasi pektin dan karagenan terhadap permen jelly nanas (Ananas comosus L. Merr). Jurnal Ilmiah Mahasiswa Pertanian Unsyiah 1: 912-923.

Juwita, W.P., H. Rusmarilin, dan E. Yusraini. 2014. Pengaruh konsntrasi pektin dan karagenan terhadap mutu permen jelly Jahe. Jurnal Rekayasa Pangan dan Pertanian 2: 42-50.

Mandey, L.C. dan C.F. Mamuaja. 2016. Teknologi produksi jam manga (Mangifera indica). Jurnal Ilmu dan Teknologi Pangan 4: 28-35.

Marsigit, W., T. Tutuarima, dan R. Hutapea. 2018. Pengaruh penambahan gula dan karagenan terhadap karakteristik fisik, kimia, dan organoleptik soft candy jeruk kalamansi (Citrofortunella microcarpa). Jurnal Agroindustri 8: 113-123. DOI: 10.31186/j.agroind.8.2.113-123

Miranti, M., B. Lohitasari, dan D.R. Amalia. 2017. Formulasi dan aktivitas antioksidan permen jelly sari buah pepaya california (Carica papaya L). Fitofarmaka 7: 36-43.

Putri, K., N. Herawati, dan F. Hamzah. 2017. Pemanfaatan daging buah kuini dalam pembuatan produk fruit leather dengan penambahan daging buah naga merah. Jom FAPERTA 4: 1-14.

Rahmi, S.L., F. Tafzi, dan S. Anggraini. 2012. Pengaruh penambahan gelatin terhadap pembuatan permen jelly dari bunga rosella (Hibiscus sabdariffa Linn). Jurnal Penelitian Universitas Jambi Seri Sains 14: 37-44.

Sachlan, P.A.A.U., L.C. Mandey, dan T.M. Langi. 2019. Sifat organoleptic permen jelly mangga kuini (Mangifera odorata Griff) dengan variasi konsentrasi sirup glukosa dan gelatin. Jurnal Teknologi Pertanian 10: 113-118.

Sebayang, E.F.B., R.J. Nainggolan, dan L.M. Lubis. 2017. Pengaruh perbandingan bubur kweni dengan sari jeruk manis dan jumlah gelatin terhadap mutu marshmallow. Jurnal Rekayasa Pangan dan Pertanian 5: 81-88.

Setyaningsih, D., A. Apriyantono, dan M. Puspitasari. 2010. Analisa Sensori untuk 
Industri Pangan dan Agro. IPB Press. Bogor.

Sudarmadji, S. 1989. Analisa Bahan Makanan dan Pertanian. PAU Pangan dan Gizi UGM, Yogyakarta.

Winarno, F.G. 2004. Kimia Pangan dan Gizi. PT. Jakarta: Gramedia Pustaka Utama.
Wulandari, E. 2015. Aktivitas Antioksidan Dan Kualitas Gummy Candy Ekstrak Akar Alang-Alang (Imperata cylindrica) Dengan Variasi Penambahan Gelatin Dan Agar-Agar Serta Pewarna Alami. Skripsi. Universitas Muhammadiyah Surakarta.

Copyright @ 2020 Nenengsih Verawati, Nur Aida, Assrorudin, Andre Wijayanto (c) () ()

This work is licensed under a Creative Commons Attribution-ShareAlike 4.0 International License. 